Diabetologia $8,371-376(1972)$

(C) by Springer-Verlag 1972

\title{
ORIGINALS
}

\section{An Abnormality of Adrenaline, Phentolamine Stimulated Lipolysis in Adipose Tissue from Obese, Maturity-Onset Diabetics}

\author{
J.N.C. Atkinson and P.J. Randle \\ Department of Biochemistry, University University of Bristol, University Walk, Bristol BS8 1TD, England
}

Received: April 4, 1972, accepted: August 24, 1972

\begin{abstract}
Summary. Abnormalities of fat metabolism from in vitro and in vivo experiments have elsewhere been described in both diabetes and obesity. In these studies adrenaline $(100 \mu \mathrm{M})$ and phentolamine $(100 \mu \mathrm{g} / \mathrm{ml})$ stimulated glycerol release has been compared in adipose tissue from groups of non-diabetic, non-obese, diabetic and obese subjects. Adipose tissue from obese diabetics showed a highly significant $(p<0.001)$ diminution in stimulated lipolysis when compared with non-diabetic, non-obese adipose tissue. The conditions of obesity and diabetes are required to be present simultaneously to maintain this difference in lipolysis. Diabetes or obesity per se are responsible for only marginally significant differences in stimulated glycerol release. The possible reasons for this defect in lipolysis in obese elderly diabetics, pertaining to fat cell receptors, the adenyl cyclase system and the hormone sensitive lipase have been discussed.
\end{abstract}

Anomalie de la lipolyse stimulée par l'adrénaline et la phentolamine dans le tissu adipeux provenant de diabétiques âgés et obèses

Résumé. Les anomalies du métabolisme de la graisse dans des expériences in vitro et in vivo ont été décrites ailleurs à la fois pour le diabète et l'obésité. Dans ces études, la libération de glycérol stimulée par l'adrénaline $(100 \mu \mathrm{M})$ et la phentolamine $(100 \mu \mathrm{g} / \mathrm{ml})$ a été comparée dans le tissu adipeux provenant de groupes de sujets nondiabétiques, non-obèses, diabétiques et obèses. Le tissu adipeux des diabétiques obèses montrait une diminution très significative $(p<0.001)$ de la stimulation de la lipolyse par comparaison au tissu adipeux des non-diabétiques et des non-obèses. Les conditions de l'obésité et du diabète doivent être présentes simultanément pour maintenir cette différence dans la lipolyse. Le diabète ou l'obésité en eux-mêmes ne sont responsables que de différences à peine significatives dans la stimulation de la li. bération de glycérol. Nous avons discuté les raisons pouvant expliquer ce défaut de la lipolyse chez les diabétiques obèses et âgés concernant les récepteurs des cellules adipeuses, le système adényle-cyclase et la lipase dépendante de l'hormone.

Anomalien bei der durch Adrenalin, Phentolamin stimu lierten Lipolyse des Fettgewebes von übergewichtigen $P a$ tienten mit spätmanifestem Diabetes

Zusammenfassung. Bei in vitro- und in vivo-Studien sind anderweitig sowohl für den Diabetes als auch für die Fettsucht Anomalien des Fettmetabolismus beschrieben worden. In dieser Arbeit wurde die durch Adrenalin $(100 \mu \mathrm{M})$ und Phentolamin $(100 \mu \mathrm{g} / \mathrm{ml})$ stimulierte Glycerinfreisetzung im Fettgewebe von Patienten ohne Diabetes, von Patienten ohne Übergewichtigkeit und bei Diabetikern mit U̇bergewicht miteinander verglichen. Das Fettgewebe von übergewichtigen Diabetikern zeigte eine hochsignifikante $(p<0,001)$ Verminderung der stimulierten Lipolyse im Vergleich zum Fettgewebe von Nicht-Diabetikern und Nicht-UUbergewichtigen. Ưbergewichtigkeit und Diabetes müssen gleichzeitig vorhanden sein, um diesen Unterschied in der Lipolyse aufrecht zu erhalten. Diabetes und Übergewicht allein sind nur für gering signifikante Unterschiede bei der stimulierten Glycerinfreisetzung verantwortlich. Die möglichen Ursachen für diesen Mangel in der Lipolyse bei übergewichtigen älteren Diabetikern, die die Fettzellrezeptoren, das Adenyl-Cyclase-System und die hormonempfindliche $\mathrm{Li}$ pase betreffen, wurden diskutiert.

Key words: Human adipose tissue, diabetes, obesity, lipolysis, catecholamines, phentolamine.
In human subcutaneous adipose tissue as in rat epididymal adipose tissue the rate of release of free fatty acids (FFA) is determined by the relative rates of lipolysis and reesterification [1]. Glycerol output by the tissue has been used as an index of the rate of lipolysis on account of its slow utilisation [2, 3]. The rate of lipolysis in vitro is increased. by hormones such as adrenaline which activate adenylcyclase and increase tissue concentrations of cyclic AMP [3-5], and decreased by insulin and prostaglandin $\mathrm{E},[5,6]$, which lower cyclic AMP concentrations. The action of cyclic AMP appears to be due to activation of triglyceride lipase as a result of phosphorylation by a cyclic AMP dependent protein kinase [7]. The effects of adrenaline on lipolysis rate and adrenyl cyclase are $\beta$-effects being inhibited by $\beta$-blockers such as propanalol [8]. Lipolysis rate in vivo and in vitro is also accelerated by insulin deficiency [9]. With human adipose tissue in vitro adrenaline or noradrenaline alone have only small effects on rates of lipolysis or tissue concentration of cyclic AMP; large stimulating effects are seen only when $\alpha$-blockers such as phentolamine are added with adrenaline $[10,11]$. Adrenaline thus has marked $\alpha$ and $\beta$-effects on human adipose tissue lipolysis and on cyclic AMP accumulation and its $\beta$-effects are most readily detected in the presence of $\alpha$-blockers. 
Elevated plasma concentrations of FFA in human diabetes are well documented especially when diabetes is severe $[12,13]$ or associated with obesity [14]. Whilst most reports have described elevation of plasma FFA in obesity [15-17], normal levels have also been reported [14]. Measurements of plasma glycerol concentrations have shown elevated levels in severe diabetes or in diabetes associated with obesity suggesting that lipolysis is increased in these conditions $[14,18]$. Experiments with adipose tissue in vitro have indicated increased rates of lipolysis with tissue from juvenile diabetics [18] but not with tissue from obese diabetics or non-diabetic obese patients. In the present study we have attempted to obtain definitive evidence on this point through a comparison of the basal rates of lipolysis in biopsy samples of adipose tissue from nondiabetic non-obese people and from people with one or both disorders of metabolism.

Insulin secretory responses to glucose are diminished in many patients with diabetes with or without obesity $[19,20]$ whereas obesity per se is frequently associated with an exaggerated insulin secretory response [19]. Since animal studies have suggested that the extent of insulin secretory responses to glucose may be modulated by cyclic AMP, Cerasi and Luft [21] have suggested that there may be a defect in the adenyl cyclase cyclic AMP system in $\beta$-cells of the pancreatic islets in diabetes. They have suggested further that this postulated defect may also occur in liver and adipose tissue cells because of the association of normal glucose tolerance with diminished insulin secretion in genetic pre-diabotics. A defect in the adenyl cyclase cyclic AMP system in adipose tissue in diabetes might therefore be expected to diminish the lipolytic response to $\beta$-effects of adrenaline. This has been investigated in the present study by comparison of the lipolytic responses to adrenaline and phentolamine of adipose tissue samples from non-diabetic, non obese, diabetic and obese people.

\section{Materials and Methods}

Patients. Diabetic patients were of the maturity onset type either untreated or treated with diet alone. Their diagnosis was confirmed by the presence of glycosuria on the day of biopsy and by either elevated fasting blood glucose concentration (levels over $100 \mathrm{mg} / 100 \mathrm{ml}$ or abnormal oral $50 \mathrm{gm}$ glucose tolerance tests (peak levels of venous blood glucose over $160 \mathrm{mg} / 100 \mathrm{ml}$ and $2 \mathrm{~h}$ levels over $100 \mathrm{mg} / 100 \mathrm{ml}$ ). Obesity was defined by a body weight at least 10 per cent in excess of standard body weight as tabulated by the Medico-Actuarial Association [22] taking into account height, age and sex. Non-diabetic non-obese subjects did not display the criteria for diagnosis of obesity or diabetes given above and were selected on the basis of age, height and sex to match the diabetic and obese subjects as closely as possible. They were either healthy volunteers, or patients undergoing abdominal surgery (for hernia repair or elective cholescystectomy for gall or gastrectomy for gastric or duodenal ulcer) or medical patients undergoing hospital investigation of neurological symptoms. Patients undergoing surgery were starved for twelve hours and given premedication and general anaesthesia. Other patients were up and about and taking a normal diet (non-diabetic) or were diabetics on a low carbohydrate diet.

Samples. Subcutaneous adipose tissue samples were taken from the abdominal wall under general or local anaesthesia. In the former case the sample was cut from the side of the abdominal incision during the operation.

Biopsy under local anaesthesia entailed the intradermal injection of approximately $0.3 \mathrm{ml} 1 \%$ lignocaine at a site in the abdominal wall lateral to the umbilicus. Care was taken to ensure that no local anaesthetic entered the dermal or subcutaneous fat layers, bearing in mind the inhibitory effect of local anaesthetics on lipolytic responses of fat cells [23]. A small incision was then made through the skin using hibitane in alcohol as an antiseptic agent. In some cases fat was removed with forceps and in others a needle biopsy technique was used.

Incubation. After removal, fat samples were placed in warmed Krobs Ringer solution containing $40 \mathrm{mg} / \mathrm{ml}$ bovine serum albumin (fraction $V$ as supplied by Armour Pharmaceutical Co.) which had been gassed with $95 \%$ $\mathrm{O}_{2} / 5 \% \mathrm{CO}_{2}$. Tissue was transported to the laboratory over a time interval of ten minutes, samples were cut into pieces weighing from 20 to $50 \mathrm{mg}$ and preincubated at $37^{\circ} \mathrm{C}$ for $30 \mathrm{~min}$ in fresh medium. The pieces of adipose tissue were then incubated for $2 \mathrm{~h}$ at $37^{\circ} \mathrm{C}$ in $0.5 \mathrm{ml}$ of the Krebs Ringer Albumin medium containing the additions mentioned in Table 1. After incubation the fat pieces were blotted and weighed. The medium was placed in ice and glycerol therein was assayed spectrophotometrically by the method of Garland and Randle [24].

Enzymes and biochemicals were obtained from Boehringer, Mannheim; (-) adrenaline from British Drug: Houses Ltd., Poole, Dorset and Phentolamine Mesylate from CIBA laboratories, Horsham, Sussex.

\section{Results}

A number of control experiments were made to define suitable conditions of incubation for this study. As shown in Fig. 1 glycerol release was proportional to adipose tissue weight in the range $10-100 \mathrm{mg}$ and samples in this weight range were used in these studies. As shown in Fig. 2 the rate of glycerol release was constant for at least two hours under the various in-

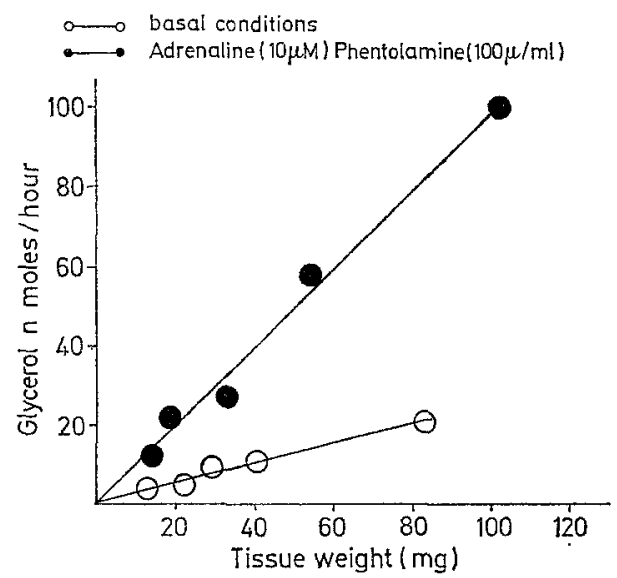

Fig. 1. Glycerol release from adipose tissue of a non-diabetic, non-obese subject to show proportionality to tissue weight 
cubation conditions used and a period of incubation of two hours was utilised. Addition of glucose $(1 \mathrm{mg} / \mathrm{ml})$ had no effect on basal glycerol output but the combined effect of adrenaline and phentolamine was enhanced as has been noted previously with rat epididymal adipose tissue. In comparing basal and stimulated rates of lipolysis in adipose tissue from patients glucose

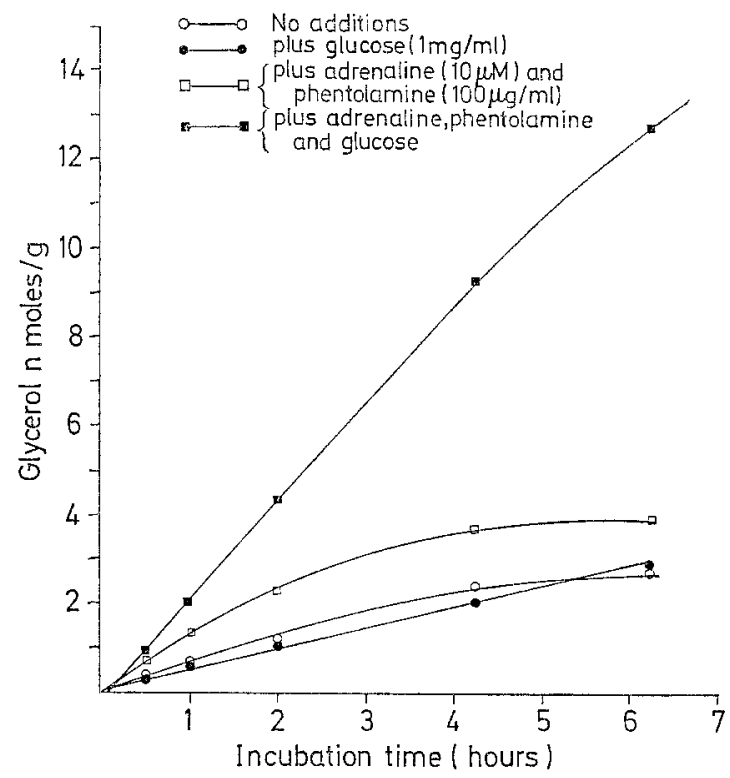

Fig. 2. Relation between length of incubation and glycerol release from adipose tissue of a non-diabetic, non-obese subject under the four different incubation conditions indicated

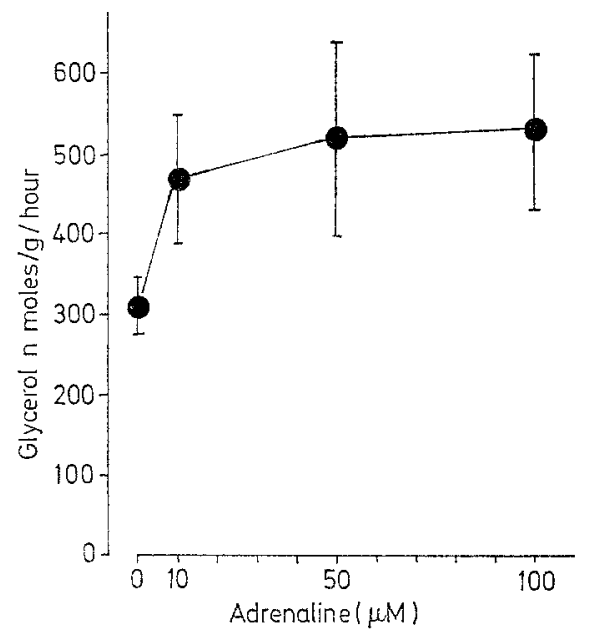

Fig. 3. Effect of adrenaline on glycerol release from adipose tissue from non-diabetic non-obese subjects. The values are the means of eight experiments

was not included in incubation media because of the possibility that variations in the rate of glucose uptake might influence glycerol output and thus complicate interpretation. Since linear output of glycerol was observed with samples of adipose tissue from the various groups studied depletion of endogenous fuels is unlikely to have occurred to complicate interpretation of the results. Figures 3 and 4 show experiments designed to define concentrations of adrenaline and phentolamine giving maximum lipolytic responses. With adrenaline alone the lipolytic response of adipose tissue from normal subjects was small and the maximum response was seen with concentrations of $10 \mu \mathrm{M}$ or above (Fig. 3) (the full concentration range studied was from $10 \mu \mathrm{M}$ to $2.5 \mathrm{mM}$ ). With adrenaline at $10 \mu \mathrm{M}$ or $100 \mu \mathrm{M}$ phentolamine markedly enhanced the lipolytic response, the maximum effect being seen with concentrations of 10 or $100 \mu \mathrm{g} / \mathrm{ml}$ in agreement with Östman and

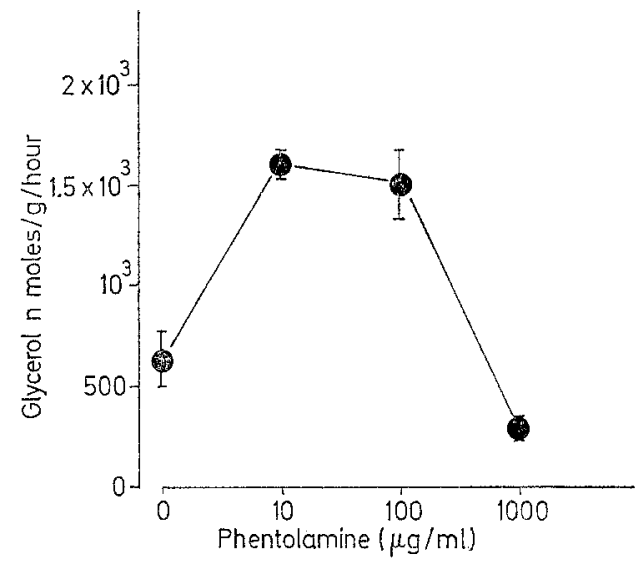

Fig. 4. Effect of phentolamine on glycerol release from adipose tissue incubated in $100 \mu \mathrm{M}$ adrenaline. Results are the means of four experiments on fat from non-diabetic non-obese subjects

Efendic [11]. In the studies to be described the concentration of phentolamine was $100 \mu \mathrm{g} / \mathrm{ml}$ and that of adrenaline 10 and $100 \mu \mathrm{M}$ (which gave indistinguishable responses).

As shown in Table 1 there were no significant differences in basal rates of lipolysis between the four groups of people (non diabetic non obese; non diabetic obese; diabetic non obese; and diabetic obese). As Table 1 also shows there were no significant differences in age, height or sex amongst the four groups. As shown in Table 2 there were no significant differences in either basal lipolysis rates or in rates after stimulation with adrenaline and phentolamine in samples from nondiabetic (obese or non obese) patients obtained under general or local anaesthesia. There were insufficient numbers of samples from diabetic patients under general anaesthesia to make meaningful comparisons of the effects of anaesthesia in this group. In considering the rates of lipolysis in Table 1 it is assumed therefore that the type of anaesthesia does not influence the lipolytic response.

The lipolytic responses to adrenaline alone (not shown in Table 1) were small and not significantly different between the various groups of patients shown in Table 1. 
When the figures for glycerol release with adrenaline and phentolamine are compared there is a highly significant difference $(p<0.001)$ between the overall groups of obese and non-obese subjects. Similarly, comparing the overall groups of diabetics and non-diabetics there is a highly significant difference $(p<0.001)$. In the diabetic group, however, there is a larger proportion of obese subjects $(60 \%)$ than in the non-diabetic group $(30 \%)$; and in the obese group there are a larger proportion of diabetics $(67 \%)$ than in the non-obese group $(33 \%)$. Further detailed analysis shows that obesity in the absence of diabetes gives rise to a significantly $(p<0.05)$ diminished lipolytic response when the difference between basal and stimulated values are considered. In the absence of obesity diabetes does not this is even more marked when obesity is combined with the diabetic state.

\section{Discussion}

In the present studies the rate of lipolysis per unit weight of subcutaneous fat in vitro under basal conditions was not influenced by obesity or maturity onset diabetes or by a combination of obesity and diabetes. This finding indicates that there is no significant influence of obesity or of maturity-onset diabetes on the basal activities of enzymes which determine lipolytic rate per unit weight of adipose tissue (e.g. adenylcyclase, hormone sensitive lipase, cyclic AMP phospho-

Table 1. Effect of adrenaline (100 $\mu \mathrm{M})$ and phentolamine $(100 \mu \mathrm{g} / \mathrm{ml})$ on lipolysis in adipose tissue from normal, obese and diabetic subjects

\begin{tabular}{|c|c|c|c|c|c|c|c|c|c|}
\hline & & \multicolumn{2}{|c|}{$\begin{array}{l}\text { Number of sub- } \\
\text { jects }\end{array}$} & Age & Height & Weight & \multicolumn{3}{|c|}{$\begin{array}{l}\text { Glycerol release (nmol/g wet } \\
\text { tissue/hour) }\end{array}$} \\
\hline & & $\begin{array}{l}\text { anaes- } \\
\text { thetic }\end{array}$ & $\begin{array}{l}\text { anaes- } \\
\text { thetic }\end{array}$ & (years) & (inches) & (pounds) & Basal & Stimulatod & Difference \\
\hline \multirow[t]{3}{*}{ Non diabetics } & Total & 12 & 27 & $54 \pm 2$ & $67 \pm 1$ & $161 \pm 7$ & $363 \pm 29$ & $1357 \pm 94$ & $994 \pm 86$ \\
\hline & Obe & 6 & 3 & 47. & & & & $3 \pm 125$ & $687+101$ \\
\hline & Non-obese & 6 & 18 & $57 \pm$ & $68=$ & $145 \pm 6$ & $357 \pm 36$ & $1466+114$ & $1109 \pm 104$ \\
\hline \multirow{3}{*}{ Diabetics } & Total & 28 & 2 & $60 \pm 2$ & $65 \pm 1$ & $174 \pm 6$ & $378 \pm 26$ & $886+105$ & $491 \mp 98$ \\
\hline & Obese & 17 & $i$ & $61 \pm 2$ & $65 \pm 1$ & $192 \pm 7$ & $361 \pm 32$ & $679 \pm 100$ & $306 \pm 96$ \\
\hline & Non-obese & 11 & 1 & $58 \pm \mathbf{3}$ & $66 \pm 2$ & $198 \pm 7$ & $404 \pm 46$ & $1172 \pm 194$ & $767 \pm 176$ \\
\hline \multirow{2}{*}{$\begin{array}{l}\text { Obese subjects } \\
\text { Non-obese } \\
\text { subjects }\end{array}$} & Total & 23 & 4 & $56 \pm 2$ & $65 \pm 1$ & $196 \pm 6$ & $367 \pm 26$ & $808 \pm 85$ & $433 \pm 79$ \\
\hline & Total & 17 & 19 & $57 \pm 2$ & $67 \pm 1$ & $146 \pm 4$ & $372 \pm 28$ & $1368 \pm 101$ & $995 \pm 93$ \\
\hline
\end{tabular}

Results are expressed as means + S.E.M.

Statistical analysis (t test): Diabotic obese vs: non diabetic obese $P<0.05>0.02$, diabetic non obese $P<0.02>$ 0.01 , non diabetic non obese $P<0.001$.

Non diabetic obese vs non diabetic non obese $P<0.05>0.02$. For other differences $P>0.05$.

Table 2. Effect of type of anaesthesia on glycerol release from adipose tissue

\begin{tabular}{lllll}
\hline \multicolumn{4}{c}{$\begin{array}{c}\text { Glycerol release nmol/g wet } \\
\text { tissue/h } \\
\text { Basal }\end{array}$} & Stimulated Difference \\
$\begin{array}{l}\text { Type of } \\
\text { anaesthesia }\end{array}$ & \\
\hline $\begin{array}{l}\text { Non dia- } \\
\text { betic }\end{array}$ & $\begin{array}{l}\text { General } \\
\text { Non obese }\end{array}$ & $\mathbf{3 4 1} \pm 44$ & $1405 \pm 136$ & $\mathbf{1 0 6 1 \pm 1 1 6}$ \\
& Local (6) & $403 \pm 55$ & $1656 \pm 201$ & $1253 \pm 238$ \\
$\begin{array}{l}\text { Non dia- } \\
\text { beticobese General (3) }\end{array}$ & $363 \pm 116$ & $\mathbf{1 1 7 6 \pm 2 7 6}$ & $813 \pm 199$ \\
& Local (6) & $389 \pm 46$ & $\mathbf{1 0 1 3} \pm 143$ & $624 \pm 119$ \\
\hline
\end{tabular}

For differences between general and local anaesthesia $P>0.05$.

cause a significant inhibition of lipolytic response but does so $(p<0.05)$ when obesity is also present. In the extremes, when non-diabetic non-obese responses are compared with those of the obese diabetic there is a highly significant difference $(p<0.001)$. It appears that while obesity per se is associated with a diminuation of adrenaline-phentolamine stimulated lipolysis diesterase, protein kinase). If these basal rates obtained in vivo then the greater mass of adipose tissue in obese individuals would be espected to give rise to a greater overall rate of lipolysis and thus to elevated plasma concentrations of FFA [14-18]. The significance of this particular finding to lipolytic rates in vivo is however of questionable significance because adipose tissue in vitro is removed from the influence of circulating hormones.

Adrenaline alone in our experiments did stimulate glycerol release in adipose tissue from normal subjects but the increase was variable and small in magnitude. In a number of experiments (not shown) there was no obvious difference in the lipolytic response to adrenaline alone of fat from normal, obese or diabetic people in confirmation (with respect to obesity) of the findings of others [25-27]. As noted previously the lipolytic response to adrenaline of fat from normal people was markedly potentiated by the $\alpha$-blocker phentolamine. This may be correlated with the much higher tissue concentrations of cyclic AMP which are seen when phentolamine is present than with adrenaline alone ([32] and unpublished observations). In experiments 
with phentolamine and adrenaline we have detected a diminished lipolytic response in fat from obese patients particularly marked when obesity was associated with maturity-onset diabetes. The effects of diabetes per se on the $\beta$-adrenergic lipolytic response was more difficult to evaluate. Fat from obese diabetic patients showed a smaller lipolytic response than fat from nondiabetic obese patients and this difference was significant at the 5 per cent level. There was however no statistically significant difference between the lipolytic responses of fat from diabetics and non-diabetics in the absence of obesity.

The impaired lipolytic responses to adrenaline and phentolamine in obesity and diabetes may be due to disturbances of one or more of a number of functions. These may include the $\beta$-adrenergic receptors, the receptors for the $\alpha$-adrenergic suppression by phentolamine, adenyl cyclase and cyclic AMP phosphodiesterase, and protein kinase and hormone sensitive lipase. It is possible also that the tissue concentrations of antilipolytic hormones such as insulin, or prostaglandins could be higher in tissue samples from obese patients. In obesity, fat cell size may be increased quite apart from fat cell number [28]. It is conceivable that the increased weight of fat per cell might of itself result in an apparent diminished lipolytic response on a unit weight basis. The present study does not allow us to distinguish between these various possibilities which are a matter for further investigations. The possible significance of the diminished lipolytic response to adrenaline and phentolamine in relation to the pathogenesis of obesity is also difficult to evaluate. The combined effects of these agents in vivo does not appear to have been investigated. Adrenaline infusion has been variously reported to produce a raised, normal [29] or diminished [30], increase in plasma FFA in obese individuals. However the effects of adrenaline in vivo are more complex than those in vitro on account of effects of the hormone on the secretion of other hormones with an influence on lipolysis, particularly insulin [31].

With regard to the pathogenesis of diabetes the finding of normal basal rates of lipolysis in fat from patients with maturity onset diabetes makes it perhaps unlikely that an inherited abnormality of adipose tissue is responsible for increased lipolysis. Presumably increased rates of lipolysis in vivo in diabetes are due to alterations in plasma concentrations of lipolytic and anti-lipolytic hormones. With regard to the possibility that a generalised defect in the maintenance of intracellular concentrations of cyclic AMP may be involved in the pathogenesis of diabetes our finding of a difference in lipolytic response to adrenaline and phentolamine between obese diabetics and obese non-diabetics could be interpreted in this way. However such a conclusion would be premature because as has been emphasised there are many other interpretations of this finding which have not been excluded by the present study. So far as we are aware there is no direct evidence for or against the idea that the adenyl cyclase cyclic AMP system may be abnormal in diabetes. In vitro studies with human fat in conjunction with currently available methods for measuring eyclic AMP concentration are capable of answering this question so far as adipose cells are concerned.

Acknowledgements. We are most grateful to Professor A. G. Riddell, Dr. J.E. Cates, Dr. D.R. Coles and the Physicians and Surgeons of the Bristol Royal Infirmary for providing tissue used in these studies. The work was supported by the Medical Research Couneil and the British Diabetic Association with whom J.N.C.A. holds a Lawrence Fellowship.

\section{References}

1. Efendić, S., Östman, J.: Catecholamines and metabolism of human adipose tissue. Acta med. scand. 187, $493-502(1970)$

2. Vaughan, M.: The production and release of glycerol by adipose tissue incubated in vitro. J. biol. Chem. 237, 3354-3358 (1962).

3. Björntorp, P.: Lipid mobilisation from human subcutaneous adipose tissue in vitro. Acta med. scand. 182, 717-726 (1967).

4. Butcher, R.W.: The role of cyclic AMP in the actions of some lipolytic and anti-lipolytic agents. In Jeanrenaud, B., Hepp, D. Adipose tissue, regulation and metabolic functions. Academic Press, p. 5-10 (1970).

5. Carlson, L.A., Hallberg, D.: Basal lipolysis and effects of norepinephrine and prostaglandin $\mathbf{E}_{1}$ on lipolysis in human subcutaneous and omental adipose tissue. J. Lab. clin. Med. 71, 368-377 (1968).

6. Moskowitz, J., Fain, J.N.: Hormonal regulation of lipolysis and phosphorylase activity in human fat cells. J. elin. Invest. 48, 1802-1808 (1969).

7. Heller, R., Steinberg, D.: Monoglyceride lipase activity of a protein kinase activatable lipase from rat adipose tissue. Fed. Proc. 30, 1090 (1971).

8. Butcher, R.W., Sutherland, E.W.: The effects of the catecholamines, adrenergic blocking agents, prostaglandin $\mathrm{E}_{1}$, and insulin on cyclic AMP levels in the rat epididymal fat pad in vitro. Ann. N.Y. Acad. Sci. 139, $849-859$ (1967).

9. Mahler, R., Stafford, W.S., Tarrant, M.E., Ashmore, J.: The effect of insulin on lipolysis. Diabetes 13, $297-302$ (1964).

10. Burns, T.W., Langley, P.E.: Lipolysis by human adipose tissue; the role of cyclic $3^{\prime} 5^{\prime}$ adenosine monophosphate and adrenergic receptor sites. J. Lab. clin. Med. 75, 983-997 (1970).

11. Östman, J., Efendić, S.: Catecholamines and metabolism of human adipose tissue. Acta med. scand. 187, $471-476$ (1970).

12. Bierman, E.L., Dole, V.P., Roberts, T.N.: An abnormality of non-esterified fatty acid metabolism in diabetes mellitus. Diabetes 6, 475-479 (1957).

13. Hales, C.N., Randle, P.J. : Effects of low carbohydrate diet and diabetes mellitus on plasma concentrations of glucose, non-esterifiod fatty acid and insulin during oral glucose-tolerance tests. Lancet 1963 I, $790-794$.

14. Bagdade, J.D., Porte, D., Bierman, E.L.: The interaction of diabetes and obesity on the regulation of fat mobilisation in man. Diabetes 18, 759-772 (1969).

15. Gordon, E.S.: Non-esterified fatty acids in blood of obese and lean subjects. Amer. J. clin. Nutr. 8, 740 $747(1960)$.

16. Opie, L., Walfish, P.G.: Plasma free fatty acid concentrations in obesity. New Engl. J. Med. 268, 757760 (1963). 
17. Beck, P., Koumans, J.H.T., Winterling, C.A., Stein, F., Daughaday, W.H., Kipnis, D.M.: Studies of insulin secretion and growth hormone secretion in obesity. J. Lab. clin. Med. 64, 654-667 (1964).

18. Östman, J.: Studies in vitro on fatty acid metabolism of human subcutaneous adipose tissue in diabetes mellitus. Acta med. scand. 177, 639-655 (1965).

19. Cerasi, E., Luft, R.: The plasma insulin responses to glucose infusion in healthy subjects and in diabetes mellitus. Acta endocr. (Kbh) 55, 278 - 304 (1967).

20. Perley, M., Kipnis, D.M. : Plasma insulin response to glucose and tolbutamide of normal weight and obese diabetic and non diabetic subjects. Diabetes 15, $867-$ $874(1966)$

21. Cerasi, E., Luft, R.: The pathogenesis of diabetes mellitus - a proposed concept. Nobel Symposium 13, $17-40(1970)$.

22. Society of Actuaries. Build and Blood Pressure Study. Vol. 1, p. 16. Chicago: 1959.

23. Hales, C.N.: Effect of local anaesthetics on the hormonal control of rat isolated fat cells. Diabetologia 6 , 47 (1970).

24. Garland, P.B., Randle, P.J.: A rapid enzymatic assay for glycerol. Nature (Lond.) 196, 987-988 (1962).

25. Mosinger, B., Kuhn, E., Kujalova, V.: Action of adipokinetic hormones on human adipose tissue in vitro. J. Lab. clin. Med. 66, 380-389 (1966).

26. Galton, D.J., Bray, G.A.: Effects of epinephrine on isolated adipose cells from normal and overweight patients. J. clin. Invest. 45, 1010 (1966).

27. Bjorntorp, P., Hood, B.: Studies on adipose tissue from obese patients. Acta med. scand. 179, $221-227$ (1966).

28. Hirsch, J., Knittle, J.L., Salans, L.B.: Cell lipid content and cell number in obese and non-obese human adipose tissue. J. clin. Invest. 45, 1023 (1966).

29. Balasse, E.: Influence of norepinephrine growth hormone and fasting on FFA mobilization and glucose metabolism in lean and obese subjects. Diabetologia 4 , $20-25(1968)$.

30. Glennon, J.A., Brech, W.J., Gordon, E. S.: Evaluation of an epinephrine test in obesity. Metabolism 14, $1240-1242(1965)$.

31. Coore, H.G., Randle, P.J.: Regulation of insulin secretion studied with pieces of rabbit pancreas incubated in vitro. Biochem. J. 93, 66-78 (1964).

32. Burns, T.W., Langley, P.E., Robison, G.A.: The influence of catecholamines on human adipose tissue lipolysis; the role of adrenergic receptor sites and $3^{\prime} 5^{\prime}$ cyclic adenosine monophosphate (c AMP). Exerpta Medica (International Congress Series) 209, 45 (1970).

Dr. J.N, Atkinson

Dept. of Biochemistry

University of Bristol

Bristol BS 81 TD/England 